\title{
Assessment of Some Heavy Metals Contamination in Some Vegetables (Tomato, Cabbage, Lettuce and Onion) in Ethiopia: A Review
}

\author{
Dagne Bekele Bahiru \\ Ethiopian Institute of Agricultural Research, Debre Zeit Agricultural Research Center, Department of Natural Resource Management, Debre \\ Zeit, Ethiopia
}

Email address:

ddagnebbk19@gmail.com

To cite this article:

Dagne Bekele Bahiru. Assessment of Some Heavy Metals Contamination in Some Vegetables (Tomato, Cabbage, Lettuce and Onion) in Ethiopia: A Review. American Journal of Environmental Protection. Vol. 10, No. 2, 2021, pp. 53-58. doi: 10.11648/j.ajep.20211002.12

Received: April 16, 2021; Accepted: May 19, 2021; Published: May 31, 2021

\begin{abstract}
Heavy metals in the soil are associated with various chemical forms that related to their solubility nature which directly bear on their mobility and biological availability. Vegetable and other crops can absorb heavy metals from soil and, deposited on the part of their tissues. The aim of this review is to assess the extent of heavy metals in some vegetables (lettuce, tomato, cabbage and onion) which are grown in different part of Ethiopia. These vegetables are staple and common vegetables consumed by all classes of Ethiopians, due to high consumption rate of these vegetables. Vegetables are vital to human being diet as they contain essential components need by the human body such carbohydrates, proteins, vitamins, minerals and also trace elements. Consumption of vegetables like tomato, lettuce, cabbage and onion are is one of the pathways by which heavy metals enter the food chain. According to different studies in Ethiopia the concentration of heavy metals in vegetables has been compared with the standard value recommended by WHO/FAO, and other organization are recorded comparative average concentrations and above the recommended limit. The higher concentration of heavy metal in vegetables might be due industrialization and agricultural activities. Based on facts obtained from different studies we suggests concerned official body (ies) to take the necessary precaution measures for agricultural activities, polluted factory effluents, gasses and solid wastes and other heavy metal source.
\end{abstract}

Keywords: Heavy Metals, Vegetables, Contamination

\section{Introduction}

Heavy metals are defined as elements in the periodic table having high atomic number, atomic weight, specific gravity greater than 5 and atomic densities of more than $5 \mathrm{~g} / \mathrm{cm}^{3}$ generally excluding alkali metals and alkaline earth metals [1]. The environmental problems associated with heavy metals are that they as elements are undestroyable and most of them have toxic effects on living organism when exceeding their limited concentration. Furthermore, some heavy metals are being subjected to bioaccumulation, geoaccumulation and may pose a risk to human health when transferred to the food chain [1].

They became concentrated due to industrialisation, urbanization, uncontrolled farming practice and can enter pant, animal and human tissues through inhalation, diet and manual handling. They can interfere with cellular components. $\mathrm{Cd}, \mathrm{Pb}, \mathrm{Cr}, \mathrm{Hg}$ and as appear among the 10 list of chemicals of major public concern to WHO [2]

Food crops for examples: fruits, tubers, vegetables and nuts that are cultivated in contaminated farm land can accumulate toxic heavy metal (HMs). Humans exposure to toxic HMs is via inhalation of dust intake of contaminated water and food crops. HM via food accumulate in the several organs causing altered metabolism in liver and kidney, cardiovascular, nervous and bone disorders [3].

Vegetables are rudimentary eating routine taken by peoples in all through the world, being wellsprings of fundamental supplements, antioxidants agents and metabolites. They likewise go about as buffering specialists for acid substance obtained during the digestion process. However, both essential and toxic components are available in vegetables over an extensive variety of concentrations as 
they are said to be great absorber of metals from the soil [4] Different plants accumulate its different concentration. Some accumulate more than others. Vegetables being carrier of metals, when taken up by human beings, get ingested into human body. Heavy metals can be exceptionally unsafe to the human body even in low concentrations as there is no powerful excretion mechanism [5]. Therefore, the present review was conducted with an aim to assess the heavy metals accumulation potential on tomato, lettuce, cabbage and onion in Ethiopia and it sources also reviewed.

\section{Sources of Heavy Metals in Vegetables}

Industrialization and urbanization has contributed elevated levels of heavy metals in the environment of developing $[5 ; 6$; $7 ; 8 ; 9]$. Heavy metals are nonbiodegradable and persistent in the environment, which deposited in soil or absorbed into the tissue of vegetables.

\subsection{Soil}

Heavy metals in the soil are associated with various chemical forms that related to their solubility nature which directly bear on their mobility and biological availability. Vegetable and other crops can absorb heavy metals from soil and, deposited on the part of their tissues. (Haiyan and Stuanes, 2003). Heavy metal toxicity can directly affect plant physiology, growth, and many case of toxicity from heavy metals have been reported. Jorgensen group show that intensive horticultural systems in urban areas may be threatened by soil toxicity through trace elements such as $\mathrm{Zn}$, $\mathrm{Cu}$, As and $\mathrm{Pb}[9]$.
Water contaminated by toxic heavy metals in some areas due to natural process and anthropogenic activities. Toxic heavy metals contamination of agricultural soil from wastewater irrigation is serious problems since it has implication on human health. The extent of absorption of heavy metals by the plant depends on the nature of the plant and the chemical constitution of the pollutant. Many studies have been shows that wastewater irrigation has increase the levels of heavy metals in the receiving $[9 ; 10 ; 11 ; 12 ; 13 ; 14]$. The accumulation of toxic heavy metals in vegetables has serious adverse effects on human health and plants [9; 15]. According to Fisseha, 2003, the Ethiopian metal tools factory is the major source of pollution of rivers, which used to irrigate part of vegetable farms. In addition to that the author reported that wastewater from eastern industry zone, Dukem Ethiopia discharged into the farm land around that park were above the recommended levels set $\mathrm{FAO} / \mathrm{WHO}$ in the vegetables produced by irrigating these contaminated water [16].

\subsection{Anthropogenic}

Anthropogenic source of heavy metals include addition of manures, sewage sludge, fertilizers and pesticides, which may affect uptake of heavy metals by vegetables [17]. Whatmuff and McBride found that, increasing concentrations of heavy metals in soil increased the crop uptake. Plant cultivation areas near in the highways, also exposed to atmospheric pollution in the form of heavy metal containing aerosols. These aerosols can deposited on soil and absorbed by the vegetables or alternatively deposited on the leaves and fruits and then absorbed $[9 ; 18 ; 19]$. Emission of heavy metals from the industries. Source of different heavy metals are presented in the Table 1.

\subsection{Wastewater}

Table 1. Source of different heavy metals: Manufacturing/Industries/Industrial effluents [9].

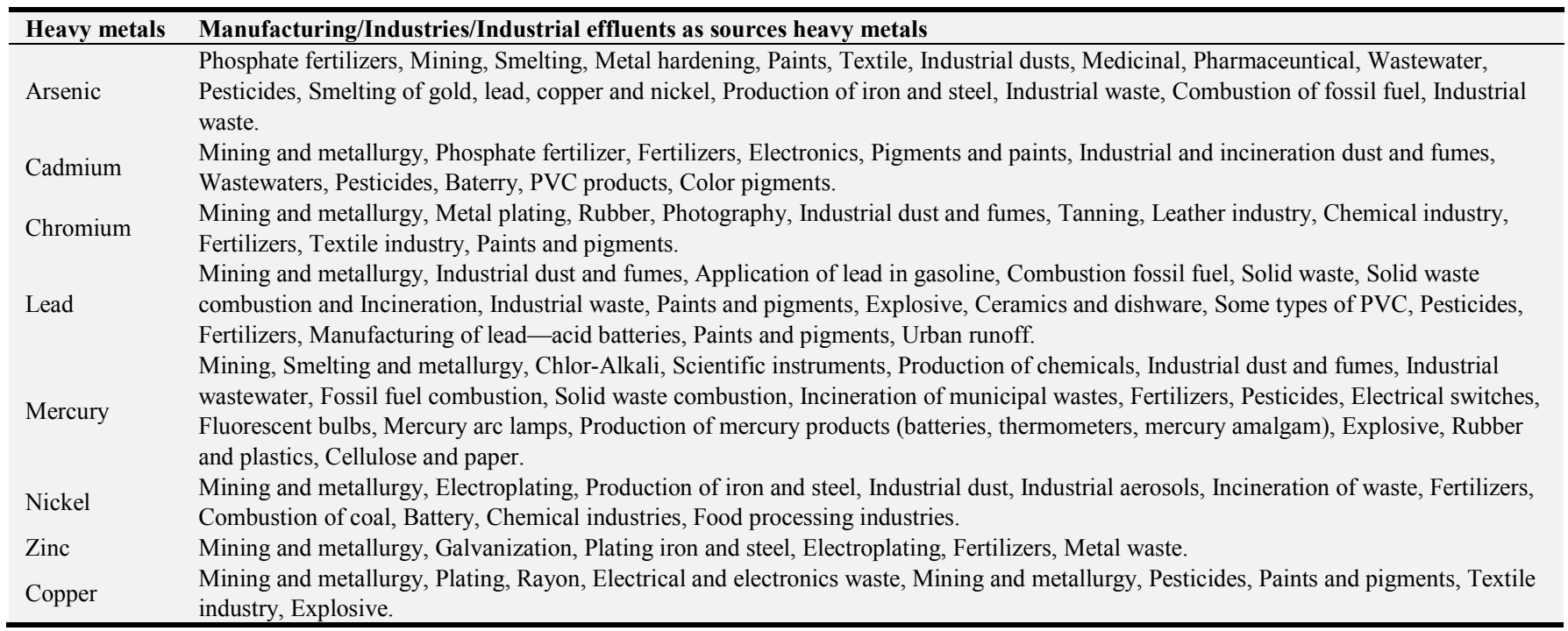

\section{Heavy Metal and Consumer Health}

Heavy metals accumulation human body in considerable amount that will bring damage the boy system, due to nonbiodegradable properties of heavy metals. They also have higher affinity towards the body system, which enables them 
to remain longer in the body. Oral exposure is the most compelling way for those heavy metals to enter the human body and cause disruption [20]. The polluted soil, water and air that transfer heavy metals in to crops indirectly involved heavy metals in the food chains that later will harm the consumers [21].

Heavy metals enter to the human body through different pathway (Figure 1) for examples dust and air pollution, conception of vegetables grown in contaminated soils $[9 ; 22$; 23]. Accordingly, assessment of heavy metals health risk give the impression necessary $[24 ; 25 ; 26]$, their fore remediation heavy metals levels is useful method for safeguard of human health [27].

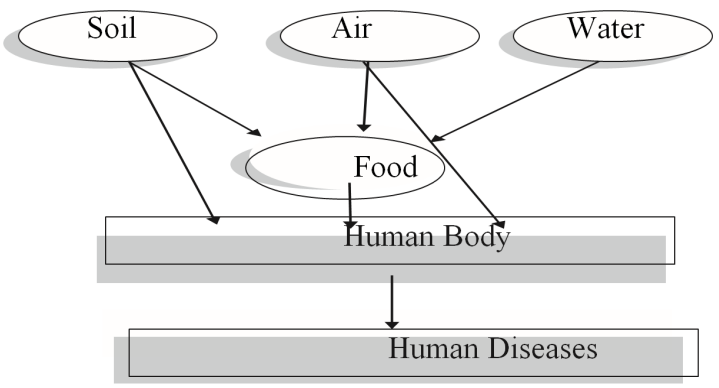

Figure 1. Different pathways of heavy metals entrance into human body.

\section{Vegetables and Heavy Metal Contamination in Ethiopia}

Vegetables are one of the diet by contributing Fe, Ca, and other nutrients. Vegetables are human diet as they contains needed by human bogs like carbohydrates, proteins, vitamins, minerals and trace elements. In recent years 2008 their consumption is increasing gradually, particularly among the urban community. This is due to increasing awareness on foods value of vegetable, as result of exposure to other cultures and acquiring proper education. However, vegetables are contains both essential and toxic elements over a wide range of concentrations [28].

Human beings are encouraged to consume more vegetables and fruits, which are a good source of vitamins, minerals, fibers and also beneficial to their health. However, these plants contain both essential and toxic metals over a wide range of concentrations. It is well known that plants take up metals by absorbing them from contaminated soils as well as from deposits on parts of the plants exposed to the air from polluted environments. The publicity regarding the high level of heavy metals in the environment has created a certain apprehension and fear in the public as to the presence of heavy metal residues in their daily food. The public is confused and alarmed about their food safety [29].

A primary concern in urban agriculture is the transfer of trace metals from vegetables through the food chain to humans. For example it has been estimated that this route contributes up to $70 \%$ of the dietary intake of $\mathrm{Cd}$. Vegetables may accumulate trace metals from contaminated soil and are also exposed to surface deposition onto their shoots in polluted atmospheric environments [23].

However, little information is available regarding human exposure to contaminants via urban agriculture in developing cities. In many cities in the developing world, there is inadequate or nonexistent waste collection, rapidly increasing traffic and largely unchecked industrial contamination. Thus, urban agriculture faces major problems in balancing demands associated with increasing populations against potential hazards arising from the use of contaminated urban sites for consumption of vegetables is one of the pathways by which heavy metals enter the food chain [23].

Difference in concertation of heavy metals in vegetables seems to imply different in different vegetable type. In spite of element uptake by root, plants are known to respond to the amount of readily mobile type of metals in soil. Different vegetable species accumulated different toxic heavy metal levels and types depending on environmental conditions, metals species and plant available forms of heavy metals [30]. A report on heavy metals levels on vegetables from Addis Ababa market showed that lettuce contained the highest $\mathrm{Cd}$ whereas cabbage accumulate the least $[31 ; 32]$. Similar trends of higher accumulation of metals in Swiss chard and low accumulation in cabbage were observed in vegetables from Akaki farm, which was irrigated with industrial effluent [33]. And also Bahiru and Bahiru and teju $[10 ; 11]$ are reported that the heavy metals accumulation in different vegetables are above the recommended levels set by different organization like FAO, WHO and in addition to those, other several studies reports in similar way as shown in Table 2

Table 2. Concentration of heavy metals in different vegetables according to different studies in Ethiopia.

\begin{tabular}{lll}
\hline Vegetable & Studied location & Source of Heavy metals \\
\hline & Around Eastern industry zone, Dukem, Central Ethiopia & Industrial effluents \\
& Gondar, Ethiopia & Urban wastewater irrigation \\
Abaya lake area, south Ethiopia & Urban waste, agricultural activity \\
Tomato & Arbaminch textile share company area, south Ethiopia & Industrial effluents \\
& Kulfo river area, south Ethiopia & Urban waste, agricultural activity \\
& Chamo lake area south Ethiopia & Urban waste, agricultural activity \\
& Zeway floriculture, Rift valley Ethiopia & Floriculture effluent \\
& Mojo, East Shewa Central Ethiopia & Leather industry effluents, agricultural practices \\
& Meki, East Shewa Central Ethiopia & floriculture farms effluents and agricultural practices \\
Znion & floriculture farms effluents and agricultural practices & Urban wastewater irrigation \\
& Gondar, Ethiopia & Urban wastewater irrigation \\
\hline
\end{tabular}




\begin{tabular}{lll}
\hline Vegetable & Studied location & Source of Heavy metals \\
\hline \multirow{4}{*}{ Cabbage } & Wonji Gefersa East Shewa Zone, Ethiopia & Contaminated Awash river water \\
& Meka Hadi East Shewa, Ethiopia & Contaminated Awash river water \\
& Gondar, Ethiopia & Urban wastewater irrigation \\
& Abaya lake area, south Ethiopia & Urban waste, agricultural activity \\
& Arbaminch textile share company area, south Ethiopia & Industrial effluents \\
& Kulfo river area, south Ethiopia & Urban waste, agricultural activity \\
& Chamo lake area south Ethiopia & Urban waste, agricultural activity \\
& Kera, Addis Ababa & Urban wastewater and industrial effluent irrigation \\
& Peacock, Addis Ababa & Urban wastewater and industrial effluent irrigation \\
Wonji Gefersa, East Shewa Zone, Ethiopia & Contaminated Awash river water \\
& Meka Hadi East Shewa, Ethiopia & Contaminated Awash river water \\
& Gondar, Ethiopia & Urban wastewater irrigation \\
Abaya lake area, south Ethiopia & Urban waste, agricultural activity \\
Arbaminch textile share company area, south Ethiopia & Industrial effluents \\
Kulfo river area, south Ethiopia & Urban waste, agricultural activity \\
Chamo lake area south Ethiopia & Urban waste, agricultural activity \\
Burayu, Addis Ababa Ethiopia & Urban waste of Gefersa River, \\
& Kuskuam Upper, Addis Ababa Ethiopia & Tap water from public water supply \\
Ziway Ethioflora, Rift valley Ethiopia & Urban waste of Ziway lake \\
Kera, Addis Ababa & Urban wastewater and industrial effluent irrigation \\
Peacock, Addis Ababa & Urban wastewater and industrial effluent irrigation \\
\hline
\end{tabular}

Table 2. Continued.

\begin{tabular}{|c|c|c|c|}
\hline Vegetable & Studied heavy metals & Levels of heavy metals in $\mathrm{mg} / \mathrm{kg}$ respectively & Reference \\
\hline \multirow{7}{*}{ Tomato } & $\mathrm{Cr}, \mathrm{Cd}, \mathrm{Zn}, \mathrm{Fe}, \mathrm{Pb}$ and $\mathrm{Cu}$ & $2.97,2.20,45.63,358.17,4.60$ and 10.20 & {$[10 ; 11]$} \\
\hline & $\mathrm{Pb}, \mathrm{Cd}, \mathrm{Cr}, \mathrm{Cu}, \mathrm{Zn}, \mathrm{Ni}$ and $\mathrm{Mn}$ & $5.95,2.43,5.80,2.01,24.61,13.88$ and 2.42 & [34] \\
\hline & $\mathrm{Cd}, \mathrm{Cr}, \mathrm{Pb}, \mathrm{Zn}, \mathrm{Cu}$ and $\mathrm{Ni}$ & $0.32,1.45,0.18,15.09,32.46$ and 15.40 & [35] \\
\hline & $\mathrm{Cd}, \mathrm{Cr}, \mathrm{Pb}, \mathrm{Zn}, \mathrm{Cu}$ and $\mathrm{Ni}$ & $0.28,1.52,0.16,10.24,19.56$ and 24.45 & [35] \\
\hline & $\mathrm{Cd}, \mathrm{Cr}, \mathrm{Pb}, \mathrm{Zn}, \mathrm{Cu}$ and $\mathrm{Ni}$ & $0.43,1.85,0.28,13.65,24.23$ and 26.89 & [35] \\
\hline & $\mathrm{Cd}, \mathrm{Cr}, \mathrm{Pb}, \mathrm{Zn}, \mathrm{Cu}$ and $\mathrm{Ni}$ & $0.41,1.70,0.21,19.56,26.37$ and 25.87 & [35] \\
\hline & $\mathrm{Cd} \mathrm{Cr} \mathrm{Pb}$ and $\mathrm{Cu}$ & $0.025,0.32,0.48$ and 0.39 & [36] \\
\hline \multirow{4}{*}{ Onion } & $\mathrm{Cr}, \mathrm{Cu}, \mathrm{Zn}, \mathrm{Pb}, \mathrm{Cd}, \mathrm{Mn}$ and $\mathrm{Fe}$ & $4.87,3.93,12.42,0.33,0.05,8.20$ and 20.87 & {$[37]$} \\
\hline & $\mathrm{Cr}, \mathrm{Cu}, \mathrm{Zn}, \mathrm{Cd}, \mathrm{Mn}$ and $\mathrm{Fe}$ & $4.13,1.33,7.71,0.03,13.40$ and 24.33 & [37] \\
\hline & $\mathrm{Cr}, \mathrm{Cu}, \mathrm{Zn}, \mathrm{Cd}, \mathrm{Mn}$ and $\mathrm{Fe}$ & $3.25,0.87,13.47,0.06,7.53$ and 0.80 & [37] \\
\hline & $\mathrm{Cd}, \mathrm{Cr}, \mathrm{Cu}, \mathrm{Zn}, \mathrm{Ni}$ and $\mathrm{Mn}$ & $3.93,6.66,2.15,19.15,9.25$ and 3.94 & [34] \\
\hline \multirow{7}{*}{ Cabbage } & $\mathrm{As}, \mathrm{Cd}, \mathrm{Cr}, \mathrm{Cu}, \mathrm{Hg}, \mathrm{Ni}$ and $\mathrm{Zn}$ & $0.105,0.018,2.815 .24,0.201,0.44$ and 15.4 & {$[38]$} \\
\hline & $\mathrm{Cr}, \mathrm{Cd}$ and $\mathrm{Pb}$ & $0.29,0.20$ and 0.30 & [39] \\
\hline & $\mathrm{Cr}, \mathrm{Cd}$ and $\mathrm{Pb}$ & $0.85,0.23$, and 0.31 & [39] \\
\hline & $\mathrm{Pb}, \mathrm{Cd}, \mathrm{Cr}, \mathrm{Cu}, \mathrm{Zn}, \mathrm{Ni}$ and $\mathrm{Mn}$ & $3.80,6.62,10.00,2.82,27.87,7.41$ and 7.27 & [34] \\
\hline & $\mathrm{Cd}, \mathrm{Cr}, \mathrm{Pb}, \mathrm{Zn}, \mathrm{Cu}$ and $\mathrm{Ni}$ & $0.30,2.05,0.31,16.40,20.65$ and 11.95 & [35] \\
\hline & $\mathrm{Cd}, \mathrm{Cr}, \mathrm{Pb}, \mathrm{Zn}, \mathrm{Cu}$ and $\mathrm{Ni}$ & $0.33,2.85,0.29,10.46,14.56$ and 18.65 & [35] \\
\hline & $\mathrm{Cd}, \mathrm{Cr}, \mathrm{Pb}, \mathrm{Zn}, \mathrm{Cu}$ and $\mathrm{Ni}$ & $0.42,2.78,0.46,14.26,16.54$ and 19.89 & [35] \\
\hline \multirow{15}{*}{ Lettuce } & $\mathrm{Cd}, \mathrm{Cr}, \mathrm{Pb}, \mathrm{Zn}, \mathrm{Cu}$ and $\mathrm{Ni}$ & $0.37,2.17,0.42,21.56,18.47$ and 17.95 & [35] \\
\hline & $\mathrm{As}, \mathrm{Cd}, \mathrm{Co}, \mathrm{Cr}, \mathrm{Cu}, \mathrm{Fe}, \mathrm{Mn}, \mathrm{Ni}, \mathrm{Pb}$ and $\mathrm{Zn}$ & $0.13,0.02,0.06,0.89,3.03,73.00,29.00,0.80,0.21$ and 31.80 & [38] \\
\hline & $\mathrm{As}, \mathrm{Cd}, \mathrm{Co}, \mathrm{Cr}, \mathrm{Cu}, \mathrm{Fe}, \mathrm{Mn}, \mathrm{Ni}, \mathrm{Pb}$ and $\mathrm{Zn}$ & $0.11,0.01,0.13,1.63,3.30,173.00,25.00,0.91,0.29$ and 31.81 & [38] \\
\hline & $\mathrm{Cr}, \mathrm{Cd}$ and $\mathrm{Pb}$ & $1.33,0.32$, and 0.40 & [39] \\
\hline & $\mathrm{Cr}, \mathrm{Cd}$ and $\mathrm{Pb}$ & $2.40,0.40$, and 0.65 & [39] \\
\hline & $\mathrm{Pb}, \mathrm{Cd}, \mathrm{Cr}, \mathrm{Cu}, \mathrm{Zn}, \mathrm{Ni}$ and $\mathrm{Mn}$ & $2.38,0.23,6.66,1.61,64.55,48.14$ and 41.52 & [37] \\
\hline & $\mathrm{Cd}, \mathrm{Cr}, \mathrm{Pb}, \mathrm{Zn}, \mathrm{Cu}$ and $\mathrm{Ni}$ & $0.18,1.55,0.19,24.34,18.55$ and 9.88 & [35] \\
\hline & $\mathrm{Cd}, \mathrm{Cr}, \mathrm{Pb}, \mathrm{Zn}, \mathrm{Cu}$ and $\mathrm{Ni}$ & $0.19,1.45,0.16,18.56,13.90$ and 15.86 & [37] \\
\hline & $\mathrm{Cd}, \mathrm{Cr}, \mathrm{Pb}, \mathrm{Zn}, \mathrm{Cu}$ and $\mathrm{Ni}$ & $0.25,1.82,0.31,22.46,16.42$ and 17.70 & [35] \\
\hline & $\mathrm{Cd}, \mathrm{Cr}, \mathrm{Pb}, \mathrm{Zn}, \mathrm{Cu}$ and $\mathrm{Ni}$ & $0.22,1.63,0.30,27.46,17.44$ and 16.81 & [35] \\
\hline & $\mathrm{Cd}, \mathrm{Cr}, \mathrm{Pb}$ and $\mathrm{Zn}$ & $0.07,1.08,1.17$ and 46.29 & {$[40]$} \\
\hline & $\mathrm{Cd}, \mathrm{Cr}, \mathrm{Pb}$ and $\mathrm{Zn}$ & $0.05,0.81,1.24$ and 36.83 & {$[40]$} \\
\hline & $\mathrm{Cd}, \mathrm{Cr}, \mathrm{Pb}$ and $\mathrm{Zn}$ & $0.03,0.76,0.52$ and 20.76 & [40] \\
\hline & $\mathrm{As}, \mathrm{Cd}, \mathrm{Co}, \mathrm{Cr}, \mathrm{Cu}, \mathrm{Fe}, \mathrm{Mn}, \mathrm{Ni}, \mathrm{Pb}$ and $\mathrm{Zn}$ & $1.04,0.13,0.76,9.47,6.62,1345.00,106.00,1.86,1.59$ and 48.03 & [38] \\
\hline & $\mathrm{As}, \mathrm{Cd}, \mathrm{Co}, \mathrm{Cr}, \mathrm{Cu}, \mathrm{Fe}, \mathrm{Mn}, \mathrm{Ni}, \mathrm{Pb}$ and $\mathrm{Zn}$ & $0.31,0.08,0.17,1.21,6.24,351.00,54.00,0.71,0.39$ and 47.80 & {$[38]$} \\
\hline
\end{tabular}

\section{Conclusion}

Heavy metals are very harmful because of their nonbiodegradable nature, long biological half-lives and their potential to accumulate in different body parts. Vegetables are vital to human diet as they contain essential components needed by the human body such as carbohydrates, proteins, vitamins, minerals and also trace elements. Consumption of vegetables is one of the pathways by which heavy metals enter the food chain. Recently, in many part of our country Ethiopia heavy metal assessment in vegetables were done by different researcher, and they report the concentration of different heavy metals in tomato, lettuce, cabbage and onion 
are above the recommended limit set by FAO, WHO, UNEPA, CMH, and other organization. These are due to industrialization, household activities, and agricultural activities like fertilizer, pesticide, and excess use of fertilizer organic materials in vegetables production. Therefore the concerned body should be give attention bout heavy metal pollution in vegetables and the researchers give attention for the heavy metal remediation techniques.

\section{References}

[1] Obasi, I. A., E. E. Nnachi, O. E. Igwe and N. P. Obasi, 2015. Evaluation of pollution status of heavy metals in the groundwater system around open dumpsites in Abakaliki urban, Southeastern Nigeria. African Journal of Environmental. Science and Technology. 9 (7): 600-601.

[2] Brathwaite R. L and Rabone, S. D (1985) Heavy metal sulphide deposits and Geochemical surveys for heavy metals in New Zealand" Journal of the Royal Society of New Zealand 15 (4): 363-370.

[3] Mahmood, A. and Malik, R. N. 2014, Human health risk assessment of heavy metals via consumption of contaminated vegetables collected from different irrigation sources in Lahore, Pakistan, Arabian Journal of Chemistry. 7: 91-99.

[4] Shakya P. R and Khwaounjoo N. M (2013) Heavy Metal Contamination In Green Leafy Vegetables Collected From Different Market Sites Of Kathmandu And Their Associated Health Risks. Scientific World, Vol. 11.

[5] Ghosh A. K, Bhatt M. A and Agrawal H. P (2012) Effect of long-term application of treated sewage water on heavy metal accumulation in vegetables grown in Northern India. Environmental Monitoring and Assessment. 184: 1025-1036.

[6] Wong, C. S. C., X. D. Li, G. Zhang, S. H. Qi and X. Z. Peng, 2003. Atmospheric depositions of heavy metals in the Pearl River Delta, China. Atmos. Environ., 37: 767-776.

[7] Khillare, P. S., S. Balachandran and B. R. Meena, 2004. Spatial and temporal variation of heavy metals in atmospheric aerosols of Delhi. Environ. Monit. Assess., 90: 1-21.

[8] Sharma, R. K., M. Agrawal and F. M. Marshall. 2008. Heavy metal $(\mathrm{Cu}, \mathrm{Zn}, \mathrm{Cd}$ and $\mathrm{Pb})$ contamination of vegetables in urban India: A case study in Varanasi. Environ. Pollut., 154: 254-263.

[9] Yeshi, Y. and Tadelewas, E. 2017. Review on Heavy Metal Contamination in Vegetables Grown in Ethiopia and Its Economic Welfare Implications. Journal of Biology, Agriculture and Healthcare. 7 (17): 3144.

[10] Bahiru B. D, and Teju E (2019) Levels of some selected metals $(\mathrm{Fe}, \mathrm{Cu}$ and $\mathrm{Zn})$ in selected vegetables and soil around eastern industry zone, central Ethiopia. African Journal of Agricultural Research Journal of Natural Sciences. 4 (2): 7891 .

[11] Bahiru B. D., Teju E., Kebede T., Demissie N. 2019. Levels of some toxic heavy metals $(\mathrm{Cr}, \mathrm{Cd}$ and $\mathrm{Pb})$ in selected vegetables and soil around eastern industry zone, central. African Journal of Agricultural Research Journal of Natural Sciences 14 (2): 92-101.
[12] Singh, K. P., D. Mohon, S. Sinha and R. Dalwani, 2004. Impact assessment of treated/untreated waste water toxicants discharge by sewage treatment plants on health, agricultural and environmental quality in waste water disposal area.

[13] Mapanda, F., Mangwayana, E. N., Nyamangara, J. \& Giller, K E. 2005. The effects of longterm irrigation using water on heavy metal contents of soils under vegetables. Agriculture. Journal of Ecosystem and Environment, 107: 151-156.

[14] Sharma, R. K., Agrawal, M. and Marshall, F. 2006. Heavy metal contamination in vegetables grown in wastewater irrigated areas of Varanasi, India. Springer science, Inc. 77: 312-318.

[15] Wenzel, W. W., Jockwer, F. 1999. Accumulation of heavy metals in plants grown on mineralised soils of the Austrian Alps. Environmental Pollution 104: 145-155.

[16] Bahiru, D. B. 2020. Determination of Heavy Metals in Wastewater and Their Toxicological Implications around Eastern Industrial Zone, Central Ethiopia. Journal of Environmental Chemistry and Ecotoxicology. 12 (2): 72-79.

[17] Yusuf, K. A. and S. O. Oluwole, 2009. Heavy metal (Cu, Zn, $\mathrm{Pb}$ ) contamination of vegetables in urban city: A case study in Lagos. Res. J. Environ. Sci., 30: 292-298.

[18] Whatmuff, M. S., 2002. Applying biosolids to acid soil in New South Wales: Are guideline soil metal limits from other countries appropriate.

[19] McBride, M. B. 2003. Toxic metals in sewage sludgeamended soils: Has proportion of beneficial use discounted the risks.

[20] Seidal, K., N. Jorgensen, C. G. Elinder, B. Sjogren and M. Vahter, 1993. Fatal cadmium-induced pneumonitis. Scand. J. Work Envrion. Health, 19: 429-431.

[21] Yang, J., Ma, S., Zhou, J., 2018. Heavy metal contamination in soils and vegetables and health risk assessment of inhabitants in Daye, China. (182). https://doi.org/10.1177/0300060518758585.

[22] Tabande L. and Taheri M. 2016. Evaluation of exposure to heavy metals $\mathrm{Cu}, \mathrm{Zn}, \mathrm{Cd}$ and $\mathrm{Pb}$ in vegetables grown in the olericultures of Zanjan province's fields. Iranian Journal of Health and Environment. 9 (1): 41-56. [In Persian].

[23] Brhane G. and Dargo H. 2014. Assessment of Some Heavy Metals Contamination in Some Vegetable and Canned Foods: A Review. International Journal of Emerging Trends in Science and Technology. 01 (09): 1394-1403.

[24] Bai J., Cui B., Chen B., Zhang K., Deng W. and Gao H, 2011. Spatial distribution and ecological risk assessment of heavy metals in surface sediments from a typical plateau lake wetland, China. Ecol Modell. 222 (2): 301-6. doi: 10.1016/j.ecolmodel.2009.12.002.

[25] Liu X., Song Q., Tang Y., Li W., Xu J., Wu J., 2013. Human health risk assessment of heavy metals in soil-vegetable system: a multi-medium analysis. Sci Total Environ. 463-464: 530-40. doi: 10.1016/j.scitotenv.2013.06.064.

[26] Yi Y., Yang Z., Zhang S. 2011. Ecological risk assessment of heavy metals in fishes in the middle and lower reaches of the Yangtze River basin. Environ Pollut. 159 (10): 2575-85. doi: 10.1016/j.envpol.2011.06.011. 
[27] Malakootian M., Mahdizadeh H., Nasiri A., Mirzaienia F., Hajhoseini M., Amirmahani N. 2018. Investigation of the efficiency of microbial desalination cell in removal of arsenic from aqueous solutions. Desalination. 438: 19-23. doi: 10.1016/j.desal.2018.03.025.

[28] Bigdeli, M. and Seilsepour M., 2008. Investigation of metals accumulation in some vegetables Irrigated with wastewater in Shahre Rey-Iran and toxicological implications, AmericanEurasian Journal of Agriculture \& Environmental Science. 4 (1): 86-92.

[29] Radwan M. A. and Salama A. K. 2006. Market basket survey for some heavy metals in Egyptian fruits and vegetables, Food and Chemical Toxicology, 44: 1273-1278.

[30] Lokeshwari, H. and Chandrappa, G. T. 2006. Impact of heavy metal contamination of Bellandur Lake on soil and cultivated vegetation. Journal of Current science, 91: 622-627.

[31] Marschner, H. 1995. Mineral nutrition of higher plants, 2nd edition. Academic Press, Toronto.

[32] Rahlenbeck, S., IBurberg,. A. and Zimmermann, R. D. 1999. Lead and Cadmium in Ethiopian Vegetables. Springer-Verlag New York Inc.

[33] Fisseha I. 1998 Metal concentrations of some vegetables irrigated with industrial liquid waste at Akaki. Ethiopia. SINET: Ethiop J Sci.; 21: 133-44.

[34] Berihun B. T., Amare D. E., Raju R. P., Ayele D. T. and Dagne H. 2021. Determination of the Level of Metallic
Contamination in Irrigation Vegetables, the Soil, and the Water in Gondar City, Ethiopia. Nutrition and Dietary Supplements. 13: 1-7.

[35] Abrham, F. and Gholap, A. V. 2021. Analysis of heavy metal concentration in some vegetables using atomic absorption spectroscopy. Pollution. 7 (1): 205-216.

[36] Mulat A., Enyew A. Z., Dawit F. and Ananda M. H. C. 2019. Determination of Heavy Metals in Tomato and its Support Soil Samples from Horticulture and Floriculture Industrial area, Ziway, Ethiopia. Res Dev Material Sci. 10 (1). DOI: 10.31031/RDMS.2019.10.000729.

[37] Bedassa M, Abebaw A, Desalegn T. 2017. Assessment of Selected Heavy Metals in Onion Bulb and Onion Leaf (Allium cepa L.), in Selected Areas of Central Rift Valley of Oromia Region Ethiopia. Journal of Horticulture. 4: 217. doi: 10.4172/2376-0354.1000217.

[38] Itanna F. 1998. Metal concentrations of some vegetables irrigated with industrial liquid waste at Akaki, Ethiopia. Ethiopian Journal of Science. 21 (1): 133-144.

[39] Banti G. 2014. Assessment of heavy metals in vegetables irrigated with Awash River in selected farms around Adama town, Ethiopia. African journal of environmental science and technology. 8 (7): 428-434.

[40] Hailu A. and Abiye T. A. 2011, Metal Concentration in Vegetables Grown in the Hydrothermally Affected Area in Ethiopia. Journal of Geography and Geology. 3 (1): 86-93. 